\title{
Southern Extension to the Breeding Range of the Gyrfalcon, Falco rusticolus, in Eastern North America
}

\author{
S. BRODEUR, ${ }^{1}$ F. MORNEAU, ${ }^{1}$ R. DÉCARIE, ${ }^{1}$ J.-L. DESGRANGES ${ }^{2}$ and J. NEGRO ${ }^{3}$
}

(Received 26 October 1994; accepted in revised form 8 December 1994)

\begin{abstract}
We report the observation of four gyrfalcon (Falco rusticolus) nests and several adults south of the previously recognized southern limit of the species' breeding distribution in eastern North America. Our southernmost observation extends the known breeding range approximately $400 \mathrm{~km}$ to the south. The northern forest tundra biome could delineate the southern limit to the breeding range of the gyrfalcon.
\end{abstract}

Key words: gyrfalcon, Falco rusticolus, nesting, distribution, Hudson Bay, Quebec.

RÉSUMÉ. Nous rapportons la découverte de quatre nids de faucon gerfaut et la mention de quelques adultes au sud de la limite connue de l'aire de reproduction de l'espèce dans l'est de l'Amérique du Nord. Notre observation la plus méridionale étend l'aire de répartition quelques $400 \mathrm{~km}$ plus au sud. Les limites sud de la toundra forestière septentrionale pourraient coincider avec celle de l'aire de reproduction du faucon gerfaut.

Mots clés: faucon gerfaut, nicheur, répartition, Baie d'Hudson, Québec.

The gyrfalcon (Falco rusticolus) is a circumboreal breeder which occurs in the arctic and subarctic regions of North America and Eurasia (Brown and Amadon, 1968). In Canada the species has been reported breeding sparsely north of $59^{\circ}$ of latitude in the arctic tundra (Godfrey, 1986). In the QuébecLabrador peninsula confirmed breeding records are few (Todd, 1963; Palmer, 1988). The southernmost location where the species has been confirmed as a breeder is Kuujjuak $\left(58^{\circ} 09^{\prime} \mathrm{N}\right.$, $68^{\circ} 18^{\prime} \mathrm{W}$ ) (Todd,1963). Audubon (1840) shot two adults near a nest on the lower north shore of the Saint Lawrence River $\left(51^{\circ} 28^{\prime} \mathrm{N}, 57^{\circ} 14^{\prime} \mathrm{W}\right)$. Both Bent (1938) and Todd (1963) considered this southerly nesting attempt as exceptional even though habitat in this area is quasi-arctic. This is probably why textbooks (e.g., Brown and Amadon, 1968; Cade, 1982; Palmer, 1988; Godfrey, 1990) show the southern limit of the breeding range of the species as being a line crossing approximately from Cape Dufferin $\left(59^{\circ} \mathrm{N}\right)$ in the eastern Hudson Bay to southern Ungava Bay $\left(58^{\circ} \mathrm{N}\right)$ (Fig. 1). Dementiev (1967) and Johansen (1956) proposed range maps that included both James Bay and Hudson Bay in the breeding range of the gyrfalcon. Johansen (1956) used his map to discuss the speciation process and sub-species distribution. Maps shown by Dementiev (1967) seem to be based wrongly on Bent (1938). Hence they presented a breeding range that was not supported by breeding data and therefore not retained in textbooks.

Data reported here were taken while doing raptor and other wildlife surveys (Brodeur et al., 1994; Morneau et al., 1994; R. Décarie, unpubl. data; J.-L. DesGranges, unpubl. data) on the eastern side of Hudson Bay from 1989 to 1992 (Fig. 1). Basins of the Great Whale, Little Whale and Nastapoka Rivers, as well as some smaller catchments farther south and the Hudson Bay coast down to Long Island were covered, although not exhaustively. The landscape is rugged and has numerous inland rocky outcrops and coastal cliffs. Vegetation types in the area are forest tundra (northern part), boreal forest (southern part) and a coastal strip of arctic tundra (Payette, 1983). Climate is subpolar (Koppen and Geiger, 1954).

Cliff-nesting raptors were surveyed from an A-Star 350 helicopter with two or three observers. Search effort focused on cliffs, which had been previously located on 1:50 000 maps, and the immediate surrounding area. Surveys were carried out in June-July 1990 and June 1991, 1992 and 1993. Other flights were done sporadically before or after the intensive surveys. A detailed account of the survey procedures was given in Morneau et al. (1994). Other wildlife surveys were also done in 1990 from an A-Star helicopter by two observers and were focused on wetlands.

On 16 June 1990, a gyrfalcon nest containing four eggs was found on Long Island, Northwest Territories. A greyphase adult attended the nest, which was on a small cliff about $11 \mathrm{~m}$ high. The nest was made of dry spruce twigs and lined with lichens. This observation extends the known breeding range of gyrfalcons approximately $400 \mathrm{~km}$ south of previous records in eastern North America. This nest was in coastal tundra, the typical breeding habitat of gyrfalcons in more northerly regions (Palmer, 1988).

\footnotetext{
${ }^{1}$ G.R.E.B.E. Inc., 2045, rue Stanley, Montreal, Quebec H3A 2V4, Canada

${ }^{2}$ Canadian Wildlife Service, Environment Canada, C.P. 10100, Sainte-Foy, Quebec G1V 4H5, Canada

${ }^{3}$ Avian Science and Conservation Centre, McGill University, 21111 Lakeshore Rd., Ste. Anne de Bellevue, Quebec H9X 3V9, Canada

(C) The Arctic Institute of North America
} 


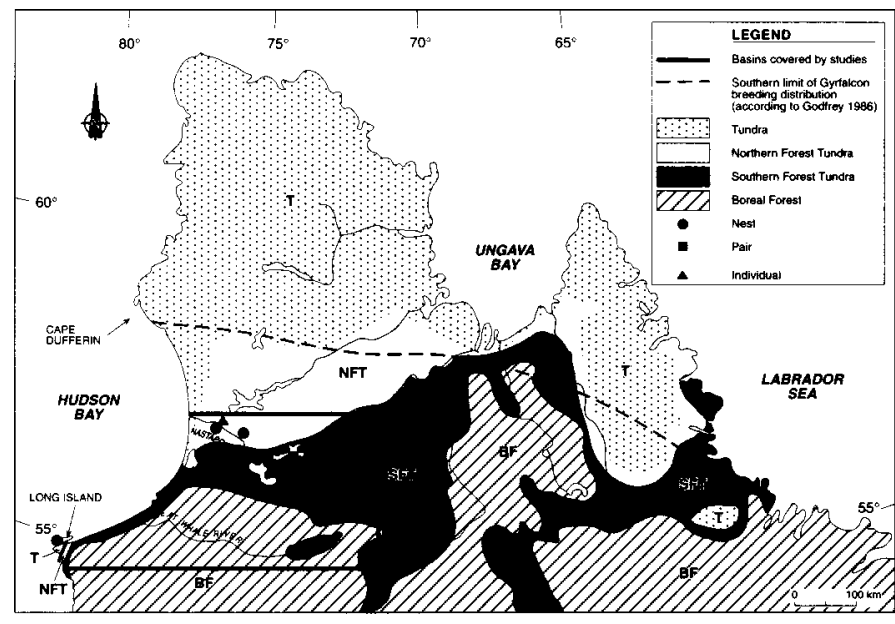

FIG. 1. Observations of the gyrfalcon east of Hudson Bay, 1990-92 (vegetation types after Payette, 1983).

On 26 July 1990, two adult gyrfalcons and a fledging, all grey-phase, were sighted flying close to an old golden eagle (Aquila chrysaetos) nest which, judging by the abundance of feces at the site, the gyrfalcons had presumably used. The nest was located on a cliff at the Du Gué River. In addition, adult gyrfalcons were observed in other parts of the study area in 1990 (Fig. 1). Some of these sightings may have involved migrating birds, as the observations were in late March (two birds observed together) and early April (two birds observed in separate places). However, one pair observed on 16 August 1990 might have attempted to breed in the area.

In 1992, two more gyrfalcon nests were found in our study area, both on cliffs surrounded by forest tundra near the Nastapoka River. One nest contained two downy chicks on 16 June. One adult was perched at the nest and the other one was nearby. Both exhibited dark-phase plumage. The second nest contained four chicks on 21 June. Two dark-phase adults were sighted nearby. These two nests, and the one located in July 1990, were near the interface between southern and northern forest tundra, the latter being a shrub sub-zone of the forest tundra (Payette, 1983).

The several breeding records reported here indicate that the gyrfalcon occupies a larger range than previously recognized. The fact that other nests have been found recently in Labrador (Joe Brazil, pers. comm. 1994) south of Godfrey's (1986) breeding range limit for the gyrfalcon supports our findings. Interestingly, this new range validates partly the one suggested by Dementiev (1967) and Johansen (1956). As the species breeds in remote areas and at low densities (Palmer, 1988), the chances of detecting nesting attempts are small unless large-scale aerial surveys are conducted. The alternative hypothesis that gyrfalcons are actually expanding their breeding range to the south cannot be discounted entirely, as gyrfalcons seem to have increased in numbers in parts of North America in recent decades (Palmer, 1988). Most nests and observations of individuals reported here lay on the borders of the southern and northern forest tundra; thus the northern forest tundra biome may define the southern breeding distribution of gyrfalcons in eastern North America.

\section{ACKNOWLEDGEMENTS}

This study was part of the Grande-Baleine hydroelectric project studies undertaken by Hydro-Québec. We wish to thank everybody that took part in the field work, especially Jean Rodrigue, Raymond McNicoll, Laurier Breton, Pierre Lafontaine and Monique Salathé. W.G. Mattox and an anonymous reviewer contributed to improving the manuscript.

\section{REFERENCES}

AUDUBON, J.J. 1840. The birds of America. Vol. 1. New York and Philadelphia: First Octavo.

BENT, A.C. 1938. Life histories of North American birds of prey. Part 2. New York: Dover Publications Inc.

BRODEUR, S., MORNEAU, F., DÉCARIE, R., NEGRO, J.J., and BIRD, D.M. 1994. Breeding density and brood size of roughlegged hawks in northwestern Quebec. Journal of Raptor Research 28(4):259-262.

BROWN, L.H., and AMADON, D. 1968. Eagles, hawks and falcons of the world. London: Country Life Books.

CADE, T.J. 1982. The falcons of the world. London: Collins.

DEMENTIEV, G.P. 1967. The gyrfalcon. Translation of Der Gerfalke (1960). Wittenberg: Neue Brehm Bucherei. Ottawa: Foreign Languages Division, Department of the Secretary of State, Government of Canada. $142 \mathrm{p}$.

GODFREY, W.E. 1986. The birds of Canada. Ottawa: National Museum of Natural Sciences. 595 p.

. 1990. Les oiseaux du Québec. Ottawa: Musée Canadien de la Nature.

JOHANSEN, H. 1956. Revision und Entstehung der Arktischen Vogelfauna. Acta Arctica. Fasc. VIII.

KOPPEN, W., and GEIGER, R. 1954. Climate of the Earth (map). Chicago: A.J. Nystrom and Co.

MORNEAU, F., BRODEUR, S., DÉCARIE, R., CARRIÈRE, S., and BIRD, D.M. 1994. Abundance and distribution of nesting golden eagles in Hudson Bay, Quebec. Journal of Raptor Research. 28(4):220-225.

PALMER, R.S., ed. 1988. Handbook of North American birds. Vol 5. New Haven and London: Yale University Press.

PAYETTE, S. 1983. The forest tundra and present tree lines of the northern Quebec-Labrador Peninsula. In: Morisset, P. and Payette, S., eds. Tree-line ecology. Proceedings of the Northern Quebec Tree-line Conference. Quebec, Canada. 3-23.

TODD, W.E.C. 1963. Birds of the Labrador Peninsula and adjacent areas: A distributional list. Toronto: University of Toronto Press. 